DOI: 10.46340/eujem.2021.7.3.8

\author{
Nataliia Halias \\ ORCID ID: https://orcid.org/0000-0001-6010-2787 \\ National Academy for Public Administration under The President of Ukraine, \\ Kyiv
}

\title{
MODELING AS A METHOD OF OPTIMIZATION OF THE KNOWLEDGE MANAGEMENT PROCESS IN THE SYSTEM OF LOCAL GOVERNANCE
}

The concepts of "model", "modeling", "mechanism", "control mechanism" are considered. Models of knowledge management processes of domestic and foreign researchers are analyzed. The study of the stages of the knowledge management process are of the particular importance. General definitions of knowledge management mechanisms in the system of local selfgovernment are provided, such as legal, organizational and information-communicative ones. The principles of formation of the complex mechanism of knowledge management in the system of local self-government are substantiated by means of a modeling method. It is worth noting that the model of optimization of the knowledge management process in the system of local selfgovernment should be iterative. On the example of this model, it is possible to distinguish a certain dependence of the efficiency of the stages of process of knowledge management and efficiency of the activity of local governments presented in model, development of potential of communities. This research examines the mechanism of knowledge management, which includes: objects of knowledge management operations and sources of knowledge; stages of the knowledge management process; and subjects of knowledge management in the system of local government, represented by the method of modeling. We use typical stages of the knowledge management process: collection of knowledge; storage and protection of knowledge; organization and structuring of knowledge; presentation, correction and updating of knowledge; distribution and dissemination of knowledge; use of knowledge; and production of knowledge. Based on the submitted material, we identify the main issues related to the use of the modeling method in relation to community capacity development. It is considered that the use of the modeling method in relation to the development of community potential allows: to study the stages of the knowledge management process before its practical implementation; to identify negative consequences that can be eliminated or mitigated; to study holistically the objects and subjects of knowledge management, the structure of the process; to provide for the establishment of internal and external influences; and to reveal the features and stages of the knowledge management process. It is vital to create an effective structure of knowledge management in the system of local self-governance to support the life cycle of knowledge as a determining intangible resource. We propose to provide knowledge management processes with timely, reliable and clear information in the practical application of this model.

Key words: knowledge management, modeling, mechanism, territorial community, system of local self-governance.

Statement of the problem. Today, knowledge is a valuable intangible resource, which is not inferior to material resources with its level of significance.

For the effective knowledge management, it is necessary to form a certain management approach, which will take into account all the properties of knowledge as a specific resource of organizations. We can imagine the knowledge management in the organization as a cycle aimed at generating and acquiring knowledge in order to improve the quality of internal processes, and these processes, in turn, ensure the emergence of new experiences and thus contribute to the generation of new knowledge ${ }^{1}$. The knowledge

\footnotetext{
${ }^{1}$ Новікова, М. М., Боровик, М. В. (2014). Організація системи управління знаннями. Науковий вісник
} 
management mechanism in the system of local self-governance includes a wide range of tools for the formation, development and use of capacity in the field of local self-governance. The creation of special mechanisms for the implementation of the functions of the subjects of management leads to the support of the life cycle of knowledge and increase the efficiency of solving local development issues. Modern realities indicate that the local self-government system needs new effective mechanisms for knowledge management, which can thus ensure the development of community capacity.

The purpose of this article is to substantiate the complex mechanism of knowledge management in the system of local self-governance using the method of modeling. To achieve this goal, it is necessary to perform the following tasks: to analyze existing models of knowledge management processes developed by foreign and domestic researchers; to create a model of a complex mechanism of knowledge management in the system of local self-governance; to formulate proposals to ensure the effectiveness of the knowledge management mechanism in the system of local self- governance.

It is worth noting that the work in the direction of research of knowledge management mechanisms in the field of public administration, in particular in the field of local self-governance, remains at an insufficient level, which determines the relevance of this topic.

Analysis of research and publications. Before we start researching the mechanism of knowledge management, we will analyze the publications of domestic and foreign scientists and identify key models of the knowledge management process.

From a number of publications of domestic and foreign scientists, we single out the following models of the knowledge management process.

Model of I. Nonaka ${ }^{1}$ is four-phase model of organizational knowledge, proposed by Japanese scientists Nonaka and Takeuchi (socialization, externalization, combination, internalization). Model of knowledge management process based on three simultaneous, closed and synchronous processes - work, study and organization, was described in the article by S. Hrynkevych ${ }^{2}$. There are also 12-step model of creating and implementing a holistic knowledge management system ${ }^{3}$ and model of the knowledge management process according to Bukovich ${ }^{4}$.

Professor H.I. Marynko ${ }^{5}$ highlights the model of G. Hedlund in his publication, who introduced the concept of organization of the $\mathrm{N}$-form as an organization based on knowledge. The main attribute of this model is the analysis of two sets of concepts: the type of implicit knowledge and the type of explicit knowledge (each type has three forms of knowledge: cognitive, skills, embodied knowledge), as well as four levels of social aggregation or four levels of carriers (individuals, small groups, organizations, interorganizational areas). Earl's model, on its side, emphasizes the difference between data, information and knowledge. He divides knowledge into three categories (three levels): accepted knowledge - science (data); feasible knowledge - thought (information); potential knowledge - experience (knowledge). Model of E. Karayanis combined information technology with managerial and organizational knowledge in knowledge management. W. Buren's model is the model of intellectual capital management, Despree and Schauel's model is a knowledge management taxonomy. Among the domestic researchers who studied and analyzed the processes of knowledge management in public administration, we can identify O.B. Kireeva, T.V. Mamatova, A.V. Rach, and N.O. Aliushyna. According to the analysis of existing developments in the field of knowledge management, this issue is in the center of attention of modern scholars, but it is insufficiently developed for public administration in general and for local government in particular.

Presentation of the main research material. Modeling is a way of studying any phenomena, processes or objects by constructing and analyzing their models. In a broad sense, modeling is one of the main categories of the theory of cognition and a key method of scientific research of systems and processes of any nature in many areas of human activity ${ }^{6}$.

Херсонського державного університету. Економічні науки, 7 (3), 134-137.

${ }^{1}$ Нонака, И., Такеучи, Х. (2003). Компания - создатель знания. Зарождение и развитие инноващий в японских фирмах. Москва, Олимп-бизнес, 384.

${ }^{2}$ Гринкевич, С. С., Зюзіна, О. О. (2014). Формування нової парадигми управління знаннями. Науковий вісник Херсонського державного університету державного. Економічні науки, 8 (2), 182-185.

${ }^{3}$ Calabrese, F. A., Orlando, C. Y. (2006). Deriving a 12-step process to create and implement a comprehensive knowledge management system. Journal of Information and Knowledge Management Systems, 36(3), 238-254.

${ }^{4}$ Букович, У., Уильямс, Р. (2002). Управление знаниями: руководство к действию. Москва, ИНФРА-М, 504.

${ }^{5}$ Маринко, Г. И. (2004). Современные модели и школы в управлении знаниями. Вестник Московского

университета. Управление (государство и общество), 2, 45-65.

${ }^{6}$ Томашевський, В. М. (2005). Моделювання систем. Київ: Видавнича група BHV, 352. 
The model is a certain conditional image of the object of study, which replaces the latter, but it complies with the original in such a way, that it allows you to gain new knowledge. The model is built to reflect the characteristics of the object (elements, relationships, structural and functional properties), significant in terms of the purpose of the study. The model as a means of understanding reality makes it possible to organize and formalize the initial ideas about the object of study. In the process of building the model, significant relationships and dependencies, the sequence of actions (algorithm) and the necessary resources are identified. As a means of communication, the model allows to formulate the basic concepts more precisely and briefly describe the system, allows to explain the causal relationships and the general structure of the system being studied and modeled ${ }^{1}$.

Since the local self-governance acts as a territorial self-organization of citizens to solve all issues of local life directly or through the bodies they elect ${ }^{2}$, we find it necessary to consider the typical stages of the knowledge management process already presented in the scientific community. In our opinion, the typical stages of the process of knowledge management in the organization are reflected in the work of Y.O. Yakovenko ${ }^{3}$. The process of knowledge management includes the following tasks: collection of knowledge - extraction and storage of knowledge that must be managed; organization and structuring of knowledge - the imposition of some structure on the collected knowledge, which is necessary for effective management; maintaining the knowledge repository in the current state - correction, updating, adding new and deleting outdated knowledge; distribution of knowledge - delivery of knowledge to those consumers who need it; use of knowledge organization of access of specific subroutines to knowledge and organization of user-friendly interface; production of knowledge - the organization of search and filtering of the necessary information, formulation and testing of hypotheses, registration of new knowledge. In this research, we will display in the Fig. 1 the mechanism of knowledge management (which includes objects of operation and sources of knowledge, stages of the process of knowledge management and subjects of knowledge management in the system of local selfgovernance) using the method of research of various phenomena and processes - modeling.

The concept of "mechanism" ("mechanisms") is widely used in many social sciences and is rightly considered as the concept of general sciences. Explanatory dictionaries often describe the mechanism in the context of social phenomena and processes as "internal structure, system of something"4.

In the definitions of the term "management mechanism" given by N. Nyzhnyk and O. Mashkov, it is "an integral part of the management system that provides influence on the factors on the state of which the result of the management object depends"; V. Malynovskyy determines it as "a set of tools for organizing management processes and ways to influence the development of managed facilities"6.

It is appropriate to depict a complex mechanism of knowledge management as a process of accumulation, storage, structuring, presentation, updating, distribution, use and production of knowledge by the subjects of management through the objects of operation. This mechanism must be iterative in nature, as well as meet certain requirements and challenges of society. It is a priority method for demonstrating the development of certain knowledge management processes, which complicates and simplifies structures.

As it was already mentioned, the purpose of local governments is to perform functions that are implemented through the formation of certain mechanisms. In the context of our study, legal, organizational and information-communicative mechanisms become essential.

One of the leading Ukrainian scholars V.I. Bordeniuk writes: "local governments participate in the implementation of the regulatory function in the form of the publication of regulations within the powers defined by law, and the implementation of administrative functions is done by acts of the use of law"7.

\footnotetext{
${ }^{1}$ Кустовська, О. В. (2005). Методологія системного підходу та наукових досліджень. Тернопіль: Економічна думка, 124.

${ }^{2}$ Хріпливець, Д. Є. (2008). Сутність місцевого самоврядування та його територіальної організації. Державне будівництво, $2<\mathrm{http}: / /$ nbuv.gov.ua/UJRN/DeBu_2008_2_37> (2021, травень, 20).

3 Яковенко, С. О. (2015). Моделі та перспективи експертного оцінювання рівня корпоративних знань для прийняття проектних рішень: автореферат дисертації на здобуття наукового ступеня кандидата технічних наук. Одеса: Одеський національний політехнічний університет, 20.

${ }^{4}$ Паращенко, Л. І. (2014). Теорія і технологї̈ формування моделі системи економічних механізмів управління загальною середньою освітою. Київ.

${ }^{5}$ Машков, О. А., Нижник, Н. Р. (1998). Системний підхід в організаиії державного управління. Київ: УАДУ, 37.

${ }^{6}$ Малиновський, В. Я. (2005). Словник термінів і понять з державного управління. Київ: Центр сприяння інституційному розвитку державної служби, 103.

${ }^{7}$ Борденюк, В. І. (2004). Співвідношення органів державної влади та оранів місцевого самоврядування: організаційно-управлінський аспект. Вісник НАДУ, 4, 312-320.
} 


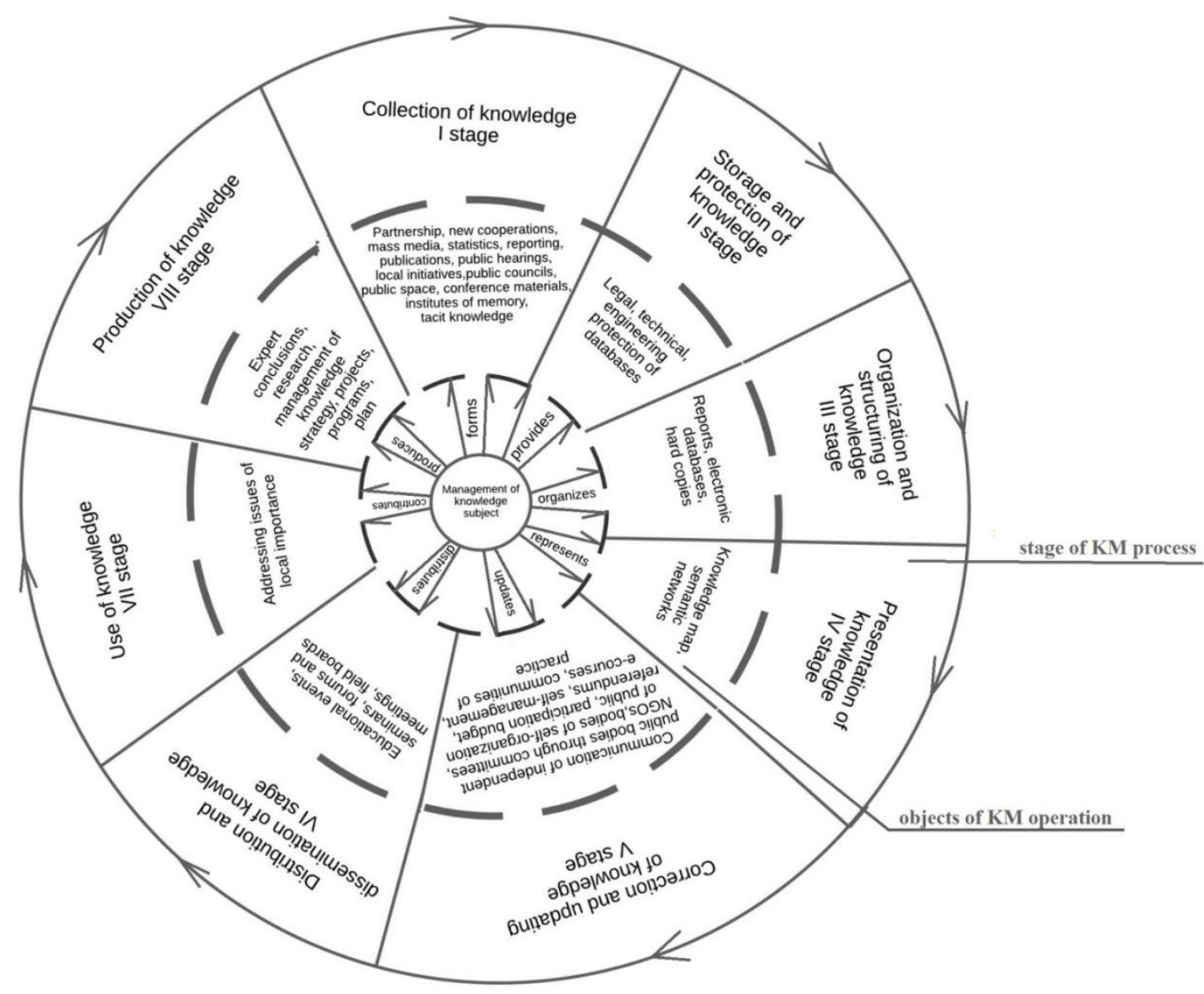

Figure 1. Model of optimization of the knowledge management process in the system of local self-governance

\section{Connections:}

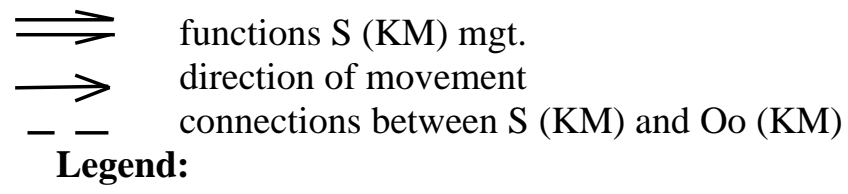

Functions $S(\mathrm{KM})$ - functions of subjects of knowledge management $\mathrm{S}(\mathrm{KM})$ - subjects of knowledge management Oo $(\mathrm{KM})$ - objects of knowledge management operation NGOs - public organizations

Source: developed by the author

In the Concept of the Statute of the territorial community of the city of Kyiv, the term "public space" appears. One of its main purposes is to provide communications in the local community, it should act as a kind of crystal lattice, which unites the core of the future community of citizens - much more powerful than today one. One of the factors that will ensure the implementation of this function is the exchange of knowledge, information, which, based on the principle of synergy, will significantly strengthen the overall intellectual potential of the city ${ }^{1}$.

\footnotetext{
${ }^{1}$ Колтун, В. С. (2017). Новий Статут територіальної громади вибудовуватиме сучасну модель місцевого самоврядування. Ukrinform <http://www.ukrinform.ua/rubric-society/2181681-viktoria-koltun-profesor-nacionalnoiakademii-derzavnogo-upravlinna-pri-prezidentovi-ukraini.html $>$ (2021, травень, 05).
} 
The essence of the organizational function is the purposeful formation of managing and managed subsystems. In our case, the model shows the subjects of management and objects of operation.

The information function in the field of local self-governance includes the involvement of the population in the solution of issues of local importance, the availability of feedback. Currently, a significant number of new information and communication technologies are emerging to implement this function in the knowledge management system.

These mechanisms of knowledge management in the system of local self-government need to be studied and improved.

Taking into account the above external and internal sources of knowledge at each stage of the knowledge management process presented in the model, one should analyze and determine the effectiveness of local governments at each stage of the knowledge management process. The model characterizes the essential features of the studied processes. The application of criteria for the effectiveness of local selfgovernment bodies will make it possible to understand whether local self-government bodies are functioning properly or whether the services provided meet the needs of communities. Among them: timeliness, reliability, clarity and completeness of information; educational level of local government officials; activity of citizens; ability to identify threats and opportunities in advance; accounting of human resources; level of technological support; positive mood of members of the territorial community, etc.

Conclusions. Because of the analysis, we have substantiated the principles of forming a comprehensive knowledge management mechanism in the local government system using the modeling method. Namely, it was found that modeling provides an opportunity to improve management procedures and make the most successful strategic decisions on local community development, also based on the study of foreign and domestic experience. We believe that the use of the method of modeling in relation to the development of community potential, allows to study the stages of the process of knowledge management to its practical implementation in reality and identify negative consequences that can be eliminated or mitigated; to study holistically the objects and subjects of knowledge management, the structure of the process; to provide for the establishment of internal and external influences; to reveal the features and stages of the knowledge management process. We have proved that the creation of an effective construction of knowledge management in the local self-governance system must be carried out to support the life cycle of knowledge as a determining intangible resource. Each stage of the knowledge management process is characterized by external and internal sources of knowledge, activities, tools of knowledge, which are an information and communication mechanisms. We have also analyzed the existing models of knowledge management processes presented by foreign and domestic researchers; thus, a model of knowledge management mechanism in the system of local self-government has been developed. Therefore, we have formed the following proposals: in the practical application of this model, it would be appropriate to ensure the processes of knowledge management with timely, reliable and understandable information; the effectiveness of local self-government bodies and the development of community potential will depend on the effectiveness of the stages of the knowledge management process presented in the model.

\section{References:}

1. Novikova, M. M., Borovyk, M. V. (2014). Orhanizatsiia systemy upravlinnia znanniamy [Organization of system of knowledge management]. Naukovyi visnyk Khersonskoho derzhavnoho universytetu. Ekonomichni nauky [Scientific Bulletin of Kherson State University. Economic Sciences], 7 (3), 134-137. [in Ukrainian].

2. Nonaka, I., Takeuchi, H. (2003). Kompaniya - sozdatel znaniya. Zarozhdenie i razvitie innovatsiy v yaponskih firmah [The Knowledge - Creating Company: How Japanese Companies Create the Dynamics of Innovation]. Moscow: Olimp-biznes. [in Russian].

3. Hrynkevych, S. S., Ziuzina, O. O. (2014). Formuvannia novoi paradyhmy upravlinnia znanniamy [Formation the new paradigm of knowledge management]. Naukovyi visnyk Khersonskoho derzhavnoho universytetu. Ekonomichni nauky [Scientific Bulletin of Kherson State University. Economic Sciences], 8 (2), 182 -185. [in Ukrainian].

4. Calabrese, F. A., Orlando, C. Y. (2006). Deriving a 12-step process to create and implement a comprehensive knowledge management system. Journal of Information and Knowledge Management Systems, 36(3), 238-254. [in English].

5. Bukovich, U., Uilyams, R (2002). Upravlenye znanyyamy: rukovodstvo $k$ deystvyyu [Knowledge management: a guide to action]. Moscow, INFRA-M. [in Russian].

6. Marinko, G. I. (2004). Sovremennyie modeli i shkolyi v upravlenii znaniyami [Modern models and schools in knowledge menegement]. Nauchnyiy zhurnal Vestnik Moskovskogo universiteta [Scientific journal Bulletin of Moscow University], 2, 45-65. [in Russian]. 
7. Tomashevskyi, V. M. (2005). Modeliuvannia system [Systems modeling]. Kyiv: Vydavnycha hrupa BHV. [in Ukrainian].

8. Kustovska, O. V. (2005). Metodolohiia systemnoho pidkhodu ta naukovykh doslidzhen [Methodology of systems approach and research]. Ternopil: Economy thought. [in Ukrainian].

9. Khriplyvets, D. Ye. (2008). Sutnist mistsevoho samovriaduvannia ta yoho terytorialnoi orhanizatsii [Essence of local self-government and his territorial organization]. State formation. [in Ukrainian].

10. Jakovenko, Ye. O. (2015). Modeli ta perspektyvy ekspertnoho otsiniuvannia rivnia korporatyvnykh znan dlia pryiniattia proektnykh rishen [Models and prospects of expert assessment of the level of corporate knowledge for project decision making]: avtoreferat dysertatsii na zdobuttia naukovoho stupenia kandydata tekhnichnykh nauk [dissertation author's abstract on scientific progress of the candidate of technical sciences]. Odessa: Odessa polytechnic state university. [in Ukrainian].

11. Parashchenko, L. I. (2014). Teoriia ta tekhnolohii formuvannia modeli systemy ekonomichnykh mekhanizmiv upravlinnia zahalnoiu serednoiu osvitoiu [Theory and technologies of model formation of the system of economic mechanisms of management of general secondary education: manual]. Kyiv: Pedahohichna dumka. [in Ukrainian].

12. Nyzhnyk, N. R., Mashkov, O. A. (1998). Systemnyi pidkhid v orhanizatsii derzhavnoho upravlinnia [System approach in the organization of public administration]. Kyiv: UADU. [in Ukrainian].

13. Malynovskyi, V. Ia. (2005). Slovnyk terminiv i poniat z derzhavnoho upravlinnia [Dictionary of terms and concepts of public administration]. Kyiv: Center for Adaptation of the Civil Service. [in Ukrainian].

14. Bordeniuk, V. I. (2004). Spivvidnoshennia orhaniv derzhavnoi vlady ta oraniv mistsevoho samovriaduvannia: orhanizatsiino-upravlinskyi aspect [The ratio of public authorities and local governments: organizational and managerial aspect]. Visnyk Natsionalnoi akademii derzhavnoho upravlinnia pry Prezydentovi Ukrainy [Bulletin of the National Academy of Public Administration under the President of Ukraine], 4, 312-320. [in Ukrainian].

15. Koltun, V. S. (2017). Novyi Statut terytorialnoi hromady vybudovuvatyme suchasnu model mistsevoho samovriaduvannia [The new Charter of the territorial community will build a modern model of local self-government]. Ukrinform <http://www.ukrinform.ua/rubric-society/2181681-viktoria-koltun-profesor-nacionalnoi-akademiiderzavnogo-upravlinna-pri-prezidentovi-ukraini.html> (2021, May, 05). [in Ukrainian]. 